University of Nebraska - Lincoln

DigitalCommons@University of Nebraska - Lincoln

Effects of gage length, loading rates, and damage on the strength of PPTA fibers

Jaeyoung Lim

Purdue University

James Q. Zheng

US Army PM-Soldier Equipment

Karl Masters

US Army PM-Soldier Equipment

Weinong W. Chen

Purdue University, wchen@purdue.edu

Follow this and additional works at: https://digitalcommons.unl.edu/usarmyresearch

Part of the Operations Research, Systems Engineering and Industrial Engineering Commons

Lim, Jaeyoung; Zheng, James Q.; Masters, Karl; and Chen, Weinong W., "Effects of gage length, loading rates, and damage on the strength of PPTA fibers" (2011). US Army Research. 134.

https://digitalcommons.unl.edu/usarmyresearch/134

This Article is brought to you for free and open access by the U.S. Department of Defense at DigitalCommons@University of Nebraska - Lincoln. It has been accepted for inclusion in US Army Research by an authorized administrator of DigitalCommons@University of Nebraska - Lincoln. 


\title{
Effects of gage length, loading rates, and damage on the strength of PPTA fibers
}

\author{
Jaeyoung Lim ${ }^{\mathrm{a}}$, James Q. Zheng ${ }^{\mathrm{b}}$, Karl Masters ${ }^{\mathrm{b}}$, Weinong W. Chen ${ }^{\mathrm{a}, *}$ \\ ${ }^{a}$ Schools of Aeronautics/Astronautics and Materials Engineering, PurdueUniversity, West Lafayette, IN 47907, United States \\ ${ }^{\mathrm{b}}$ US Army PM-Soldier Equipment, Haymarket, VA 20169, United States
}

\section{A R T I C L E I N F O}

\section{Article history:}

Received 27 January 2010

Received in revised form

16 September 2010

Accepted 24 November 2010

Available online 2 December 2010

\section{Keywords:}

Gage length

Loading rates

High-performance fibers

Transverse compression

\begin{abstract}
A B S T R A C T
Axial tension and transverse compression experiments on single fibers were performed to investigate the mechanical behavior of three high-performance fibers (Kevlar ${ }^{\circledR}$, Kevlar ${ }^{\circledR} 129$, and Twaron $^{\circledR}$ ) with diameters in the order of 9-12 $\mu \mathrm{m}$. The single fibers were manufactured from 1998 through 2008. A miniaturized tensile Kolsky bar was used to determine the tensile response of PPTA single fibers at a high strain rate. Gage length and strain rate were found to have minimum effects on the tensile strength of PPTA single fibers. Manufacturing time over a decade was found to have negligible effects on the tensile strength of the fibers. Initial transverse compression on the fibers reduces their ultimate tensile strengths. A high resolution scanning electron microscope (SEM) was also used to examine the fracture modes of transversely deformed fibers. Different types of fracture morphology were observed.
\end{abstract}

(C) 2010 Elsevier Ltd. All rights reserved.

\section{Introduction}

$\operatorname{Kevlar}{ }^{\circledR}$ and Twaron ${ }^{\circledR}$ are a type of aramid that consists of highly oriented long molecular chains produced from poly-paraphenylene (PPTA), which results in a high level in tenacity and modulus as well as anisotropy in their mechanical behavior. They are much stronger along the axial direction than across it. Those fibers, similar to many other high high-performance fibers, can be regarded as linear elastic, transversely isotropic, and homogeneous materials $[1,2]$.

Kevlar® brand para-aramid fiber, which was originally developed at DuPont ${ }^{\mathrm{TM}}$ in 1965, has high strength, light weight, and good stability at high temperatures. Over the last three decades, Kevlar ${ }^{\circledR}$ fiber has been used in flexible armors and other impact-resistant applications due to its unique combination of properties. To develop predictive capabilities of impact events involving highperformance fibers, it is critical to determine single filament properties at high strain rates.

There have been a string of analytical, numerical, and experimental investigations to determine the high-rate mechanical behavior of PPTA high high-performance fabrics or fiber bundles [3-9]. Parga-Landa and Hernandez-Olivares [3] proposed a simple analytical model to simulate the impact behavior of soft armors in which fibers are assumed to be linear elastic material. Gu [4] predicted the deformed shape of the multi-layered planar plain-woven

\footnotetext{
* Corresponding author. Tel.: +1 765494 1788; fax: +1 7654940307.

E-mail address: wchen@purdue.edu (W.W. Chen).
}

fabric under ballistic impact through analytical modeling, in which strain- rate effect on the fiber bundles was considered. Lim et al. [5] performed numerical simulations of ballistic impact on Twaron ${ }^{\circledR}$ fabric. The fiber material model includes viscoelasticity and a strain rate-sensitive failure criterion. Shim [6] and Tan [7] showed that the tensile behavior of Twaron ${ }^{\circledR}$ fabrics is highly strain-rate dependent; as the strain rate increases the failure strain decreases while the tensile strength and modulus increase. More recently, Languerand et al. [8] performed dynamic tests on PPTA fiber bundles using a conventional tension Kolsky bar. They showed no significant strain rate effect on the elastic modulus in PPTA fiber bundles. Cheng et al. [9] performed tensile experiments on a single Kevlar ${ }^{\circledR}$ KM2 fiber under high strain rate loading. Based on the experimental results, they observed that the tensile strength of Kevlar ${ }^{\circledR} \mathrm{KM} 2$ single fiber had no strain rate sensitivity along its axial direction. However, few studies on the dynamic behavior of a single fiber, especially the transverse compression effect on tensile strength of the fiber at high strain rates, are available despite its obvious importance. In application to body armor systems, individual fibers should maintain their axial strength to protect the body from the ballistic projectiles which compress transversely on the fibers.

The purpose of this study is to investigate the mechanical behavior of single Kevlar ${ }^{\circledR}$ and Twaron ${ }^{\circledR}$ fibers at both quasi-static and high strain rates. Test parameters are systematically varied, which include the directions of the fibers in a fabric, loading rates, gage length, transverse compression, and aging. A miniaturized tension bar was used to determine the tensile responses of the 
Table 1

PPTA fibers studied in this paper.

\begin{tabular}{llc}
\hline Fiber Type & Density $\left(\mathrm{Kg} / \mathrm{m}^{3}\right)$ & Diameter $(\mu \mathrm{m})$ \\
\hline Kevlar $^{\circledR}$ & 1440 & $11.22 \pm 0.16$ \\
Kevlar $^{\circledR} 129$ & 1440 & $11.89 \pm 0.28$ \\
Twaron $^{\circledR}$ & 1450 & $9.37 \pm 0.12$ \\
\hline
\end{tabular}

single fibers at the strain rate of $\dot{\varepsilon} \approx 1500 \mathrm{~s}^{-1}$. A high-resolution scanning electron microscope (SEM) was used to observe the fracture modes of the failed ends of a single fiber. The diameter of each fiber was also measured by this SEM.

\section{Experimental results and discussion}

\subsection{Materials}

Three different types of high high-performance single PPTA fibers are chosen for the experimental study; $\operatorname{Kevlar}^{\circledR}, \operatorname{Kevlar}^{\circledR} 129$, and Twaron ${ }^{\circledR}$ fibers which are listed in Table 1, together with their average diameters measured in this study. Single Kevlar ${ }^{\circledR}$ and Twaron ${ }^{\circledR}$ fibers are carefully extracted from yarns in both warp and weft (fill) directions from a woven fabric, as shown in Fig. 1 (a) and (b). The Kevlar ${ }^{\circledR} 129$ fibers are taken from a yarn that has not gone through a weaving process. An SEM image of a single fiber is shown in Fig. 1(c). A single fiber with 9-12 $\mu$ m diameter shown in Fig. 1(c) is nominally considered round and uniform.

\subsection{Quasi-static experiments}

The quasi quasi-static longitudinal tensile experiments are performed according to the ASTM standard test method for tensile strength and Young's modulus of fibers (C1577-03) with a hydraulically driven MTS810 machine at a constant crosshead speeds (Fig. 2). Tensile loading and displacement are measured directly by a load cell (Interface Inc.) with a capacity of $220.24 \mathrm{~N}$ (50 lbf) and an extensometer (Epsilon Technology Corp.) of $\pm 1.25 \mathrm{~mm}$, respectively.

Figs. 3-5 show the tensile stress-strain behavior of the PPTA single fibers in terms of the engineering stress and engineering strain at a strain rate of $0.001 / \mathrm{s}$. The Kevlar ${ }^{\circledR}$ and Twaron ${ }^{\circledR}$ single fibers are taken from the yarns in the warp direction of the fabric. The Kevlar ${ }^{\circledR} 129$ fibers are from a virgin yarn without a weaving history. Only five of the fifteen repeated tests are shown for the

a

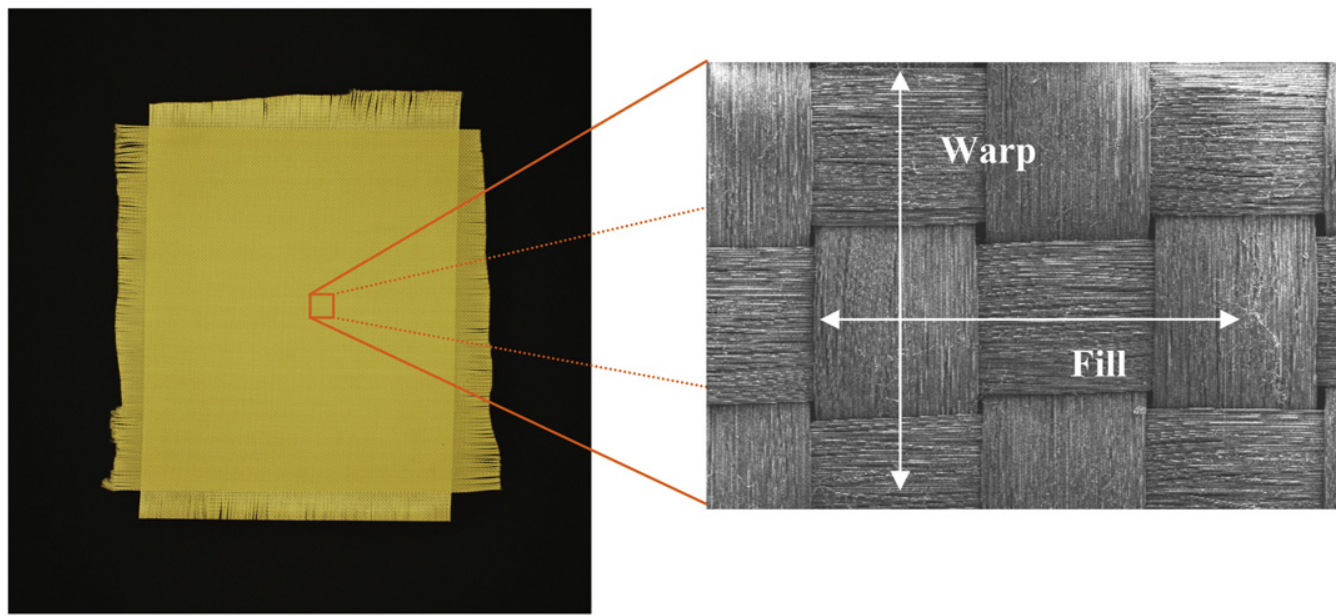

PPTA fabric showing the warp and fill directions
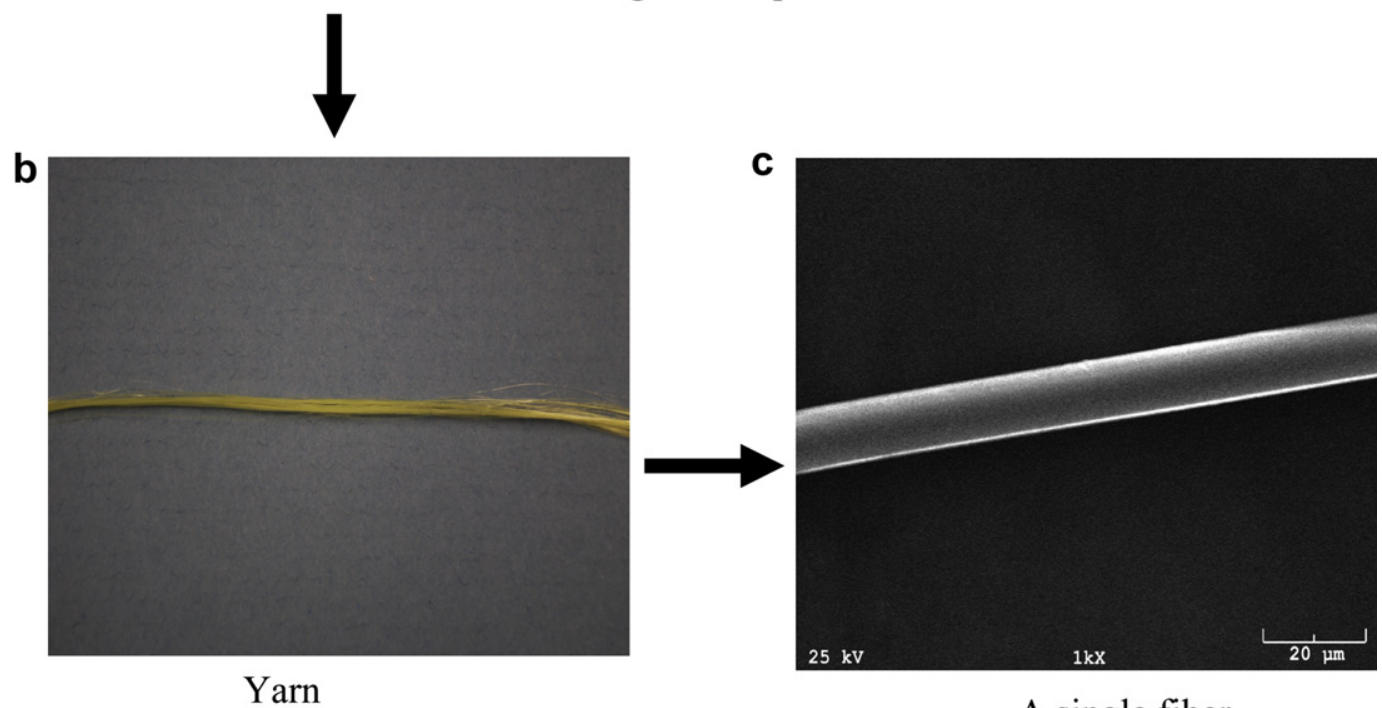

A single fiber

Fig. 1. $\operatorname{Kevlar}^{\circledR}$ fabric (a), yarn (b) and fiber (c). 
a

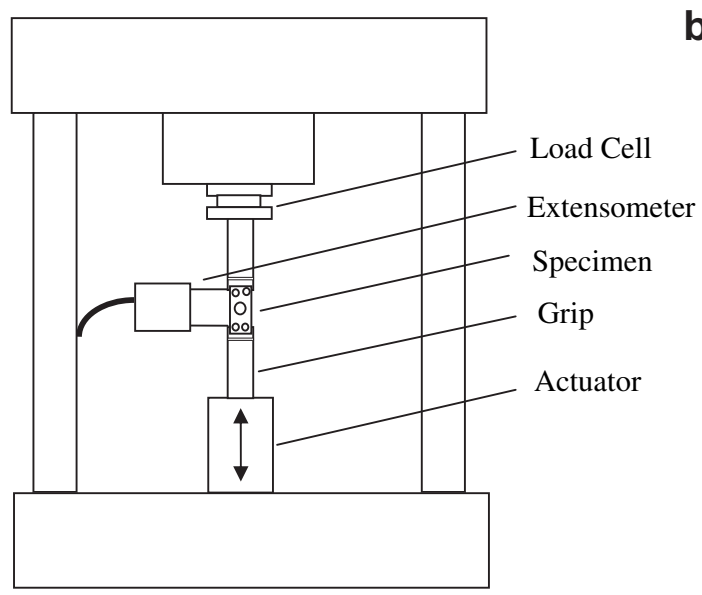

b

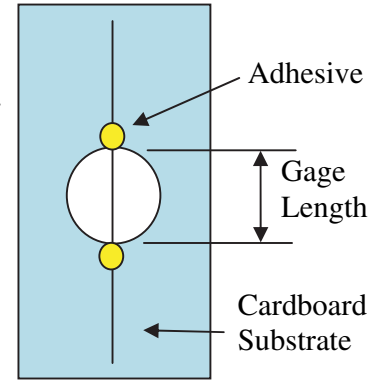

Fig. 2. Uniaxial tensile experimental setup on a quasi-static MTS810 machine (a) and tension specimen (b).

purpose of clarity. As shown in these figures, the single PPTA fibers exhibit a very linear stress-strain relationship up to the point of failure. The slope of the linear portion of a curve is the Young's modulus and the failure point is the ultimate strength of the fiber along its axial direction. There are variations in the failure stresses and failure strains of the fibers, but the elastic modulus is consistent from experiment to experiment. The longitudinal Young's modulis $E_{3}$ of $\operatorname{Kevlar}^{\circledR}, \operatorname{Kevlar}^{\circledR} 129$, and Twaron ${ }^{\circledR}$ single fibers are measured to be $109.39 \pm 5.45 \mathrm{GPa}, 108.98 \pm 3.40 \mathrm{GPa}$, and $152.49 \pm 9.22 \mathrm{GPa}$ with $95 \%$ confidence interval from the results of fifteen repeated tests on each type of fiber. The ultimate strengths of Kevlar ${ }^{\circledR}$, $\operatorname{Kevlar}^{\circledR} 129$, and Twaron $^{\circledR}$ single fibers are measured to be $4.83 \pm 0.29 \mathrm{GPa}, 4.40 \pm 0.16 \mathrm{GPa}$, and $4.74 \pm 0.32 \mathrm{GPa}$, respectively. The experimental values of the longitudinal mechanical properties for Kevlar ${ }^{\circledR}$ and Twaron ${ }^{\circledR}$ single fibers are summarized in Table 2.

\subsubsection{Gage length effects}

The purpose of this set of experiments is to examine the possibility of containing a strength-limiting defect over a certain length of the fiber. In some fibers, the possibility of including

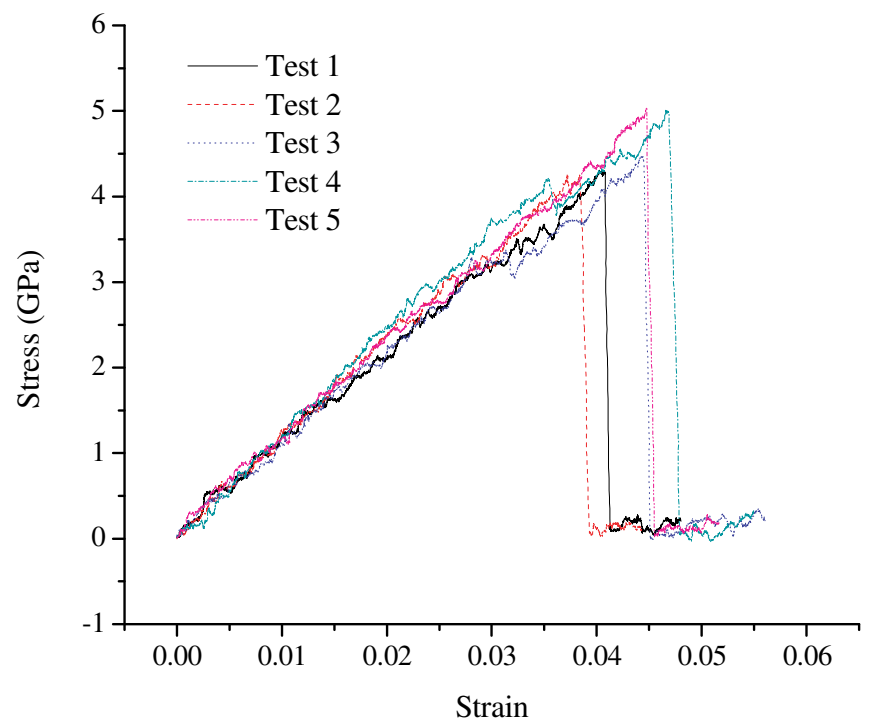

Fig. 3. Tensile stress-strain response of $\operatorname{Kevlar}^{\circledR}$ single fiber in the warp direction at a strain rate of $0.001 / \mathrm{s}$ (Gage Length $=10 \mathrm{~mm}$ ). a defect is increased by increasing the gage length. A significant defect will limit the tensile strength of the fiber. As shown in a previous research [10], the tensile strength of A265 single fiber increases with decreasing gage length when the gage length is less than $10 \mathrm{~mm}$. When the gage length is longer than $10 \mathrm{~mm}$, the strength does not vary significantly with further increasing gage length. This indicates a certain event of containing a strengthlimiting defect in a fiber with a length of $10 \mathrm{~mm}$ or longer.

To study the gage-length effects on the PPTA single fibers studied in this research, in addition to the tensile experiments at a gage length of $10 \mathrm{~mm}$, quasi-static tensile experiments are also performed at five other different gage lengths of 2.5, 5.5, 50, 100, and $250 \mathrm{~mm}$. All experiments are carried out at the same strain rate of $0.001 / \mathrm{s}$. The ultimate strengths of $\operatorname{Kevlar}^{\circledR}$ and Twaron ${ }^{\circledR}$ single fibers (from warp directions) at each gage length shown in Fig. 6 are with 95\% confidence interval from the results of fifteen repeated tests on each fiber.

Fig. 6 shows the variations of the ultimate strengths of the Kevlar $^{\circledR}$ and Twaron ${ }^{\circledR}$ single fibers over the gage length range. The experimental results show that the effect of the gage length on

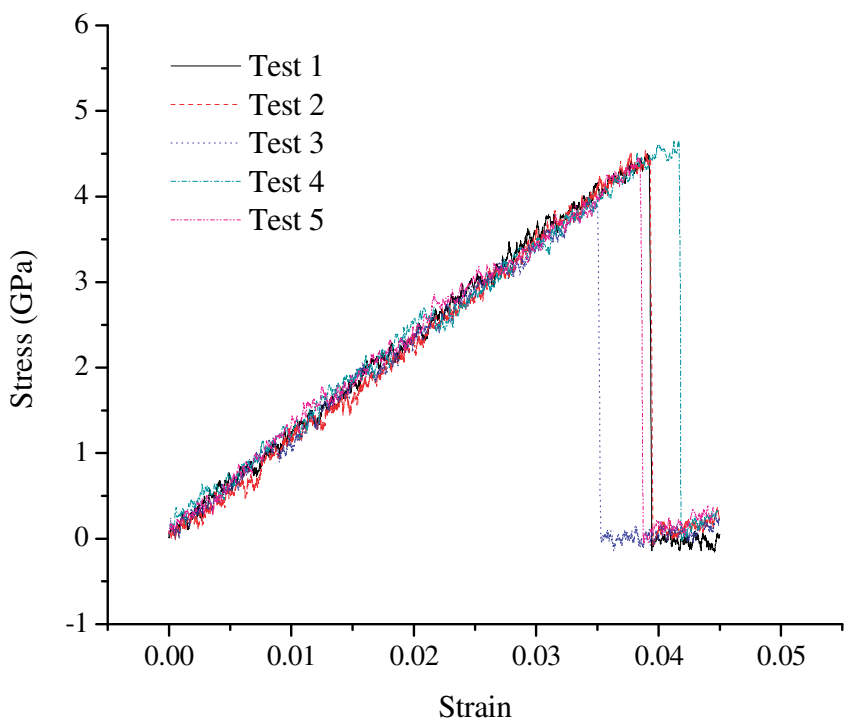

Fig. 4. Tensile stress-strain response of $\operatorname{Kevlar}^{\circledR} 129$ single at a strain rate of $0.001 / \mathrm{s}$ (Gage Length $=10 \mathrm{~mm}$ ). 


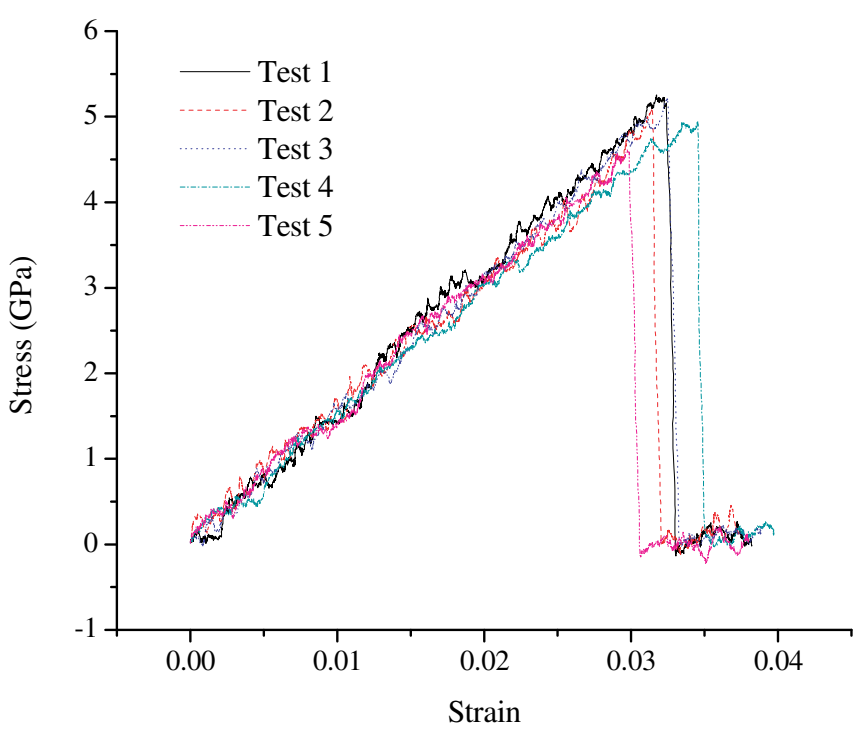

Fig. 5. Tensile stress-strain response of Twaron ${ }^{\circledR}$ single fiber in the warp direction at a strain rate of $0.001 / \mathrm{s}$ (Gage Length $=10 \mathrm{~mm}$ ).

the tensile strengths of these fibers is insignificant as shown in Fig. 6. As a comparison, literature reports that the tensile strengths of some PBO and PIPD fibers increase with decreasing gage length $[11,12]$. The little variations in the tensile strengths of the fibers studied in this paper may indicate that the strength-limiting defects are quite numerous and evenly distributed along these fibers.

\subsubsection{Effects of aging}

The mechanical properties of many polymer products degrade over extended periods of time. This is a concern for flexible armors made of polymeric fibers. We conducted tensile experiments on Kevlar $^{\circledR}$ and Twaron $^{\circledR}$ single fibers manufactured from 1998 through 2008, which was stored at normal laboratory room condition. The results are shown in Fig. 7 where the ultimate tensile strength is plotted against the manufacturing year of the fibers. The results show that the $\operatorname{Kevlar}^{\circledR}$ and Twaron ${ }^{\circledR}$ single fibers, made within a span of 10 years, have a little variation in its tensile strength for both warp and fill directions. The results shown in Fig. 7 also indicate that the differences in tensile strengths of fibers taken from warp and fill directions are not significant.

\subsection{High strain rate experiments}

\subsubsection{A miniaturized tension Kolsky bar}

In order to determine the tensile response of high high-performance single fiber at high rates, we modified a Kolsky tension bar, also called a split Hopkinson tension bar (SHTB) for single-fiber tests. The concept of Kolsky bar, introduced by Kolsky [13] first in 1949 for compression experiments, has been widely used to determine stress-strain relations in materials under dynamic loading at high

Table 2

Longitudinal mechanical properties of PPTA single fiber at quasi-static.

\begin{tabular}{|c|c|c|c|c|}
\hline Fiber type & $\begin{array}{l}\text { Tenacity } \\
\text { (g/denier) }\end{array}$ & $\begin{array}{l}\text { Ultimate } \\
\text { strength (GPa) }\end{array}$ & $\begin{array}{l}\text { Failure } \\
\text { strain (\%) }\end{array}$ & $\begin{array}{l}\text { Young's } \\
\text { modulus (GPa) }\end{array}$ \\
\hline Kevlar $^{(}$ & 38.0 & $4.83 \pm 0.29(w)^{a}$ & $4.42 \pm 0.26(w)$ & $109.39 \pm 5.45(w)$ \\
\hline Kevlar $^{\circledR} 129$ & 34.6 & $4.40 \pm 0.16$ & $4.05 \pm 0.17$ & $108.98 \pm 3.40$ \\
\hline Twaron $^{\circledR}$ & 37.3 & $4.74 \pm 0.32(w)$ & $3.12 \pm 0.22(\mathrm{w})$ & $152.49 \pm 9.22(\mathrm{w})$ \\
\hline
\end{tabular}

${ }^{\mathrm{a}} \mathrm{w}$ indicates the warp direction of the fiber in a single ply.

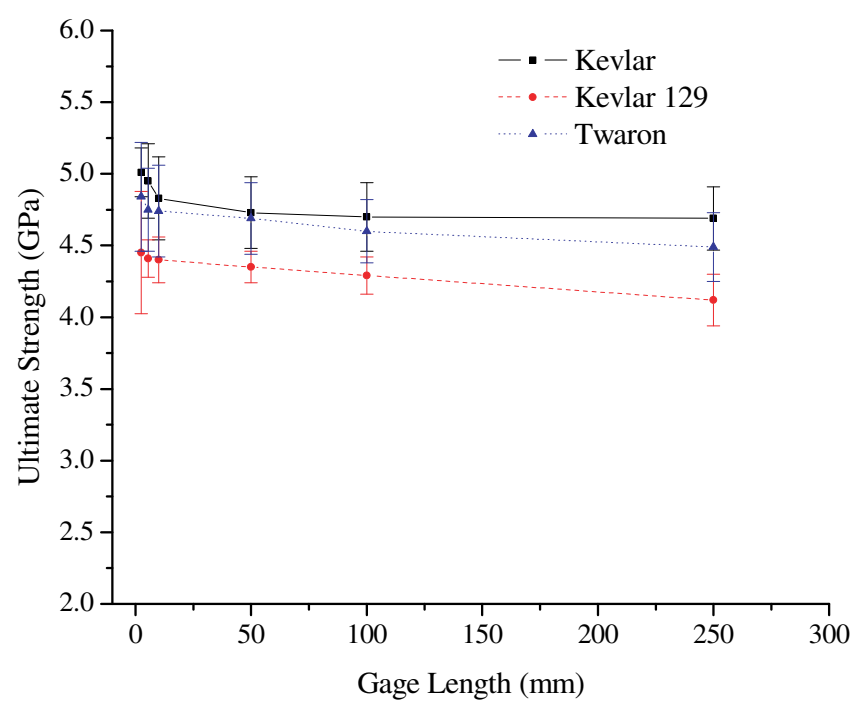

Fig. 6. Variations of the ultimate strength of PPTA single fibers in the warp direction over the gage length.

strain rates [14,15]. A conventional SHTB apparatus consists of a striker tube, an incident bar with a flange, and a transmission bar [16]. As the striker tube impacts the flange head of an incident bar, a tensile elastic stress wave called incident stress wave is generated and propagated through the incident bar. When the incident stress wave reaches the specimen, the elastic wave is partly transmitted through the specimen and partly reflected back to the incident bar due to the mismatch of the mechanical impedances at the interface between the incident bar and specimen [17]. In our miniaturized tension bar, however, the transmitted stress wave becomes too small to measure due to the small fiber specimen. For this reason, the transmitted stress signal cannot be detected using a conventional transmission bar. In the experimental setup used in this study, the transmission bar is replaced by a quartz-piezoelectric load cell with a capacity of $22.24 \mathrm{~N}$ (5 lbf), as shown in Fig. 8(a).

A photograph of a miniature tension bar for a single fiber test at high strain rate is shown in Fig. 9. The miniature tension bar we used consists of an incident bar with a flange, a fiber specimen, and a load

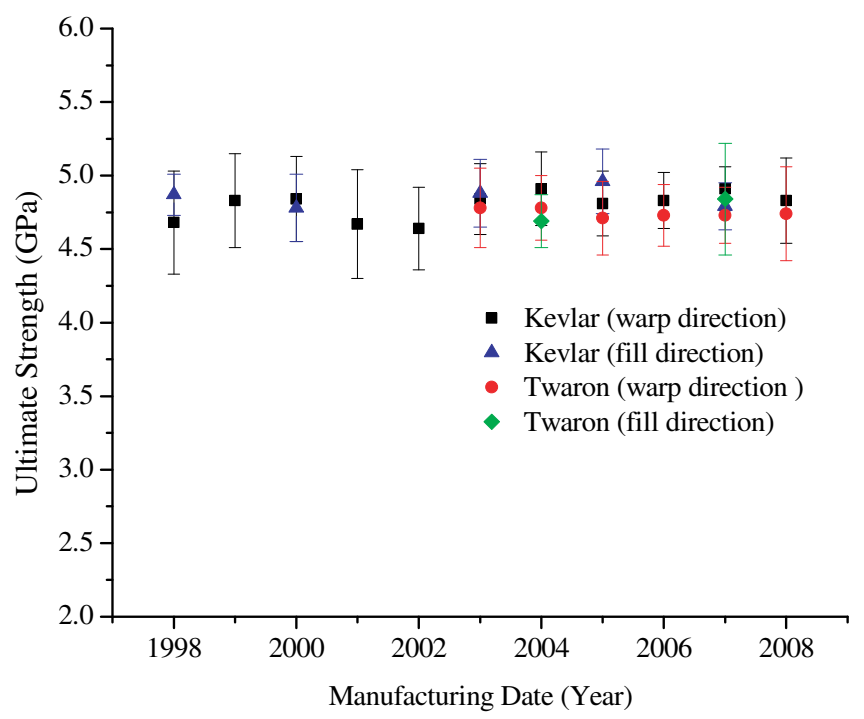

Fig. 7. Variations of the ultimate strength of PPTA single fibers over the year of manufacture. 


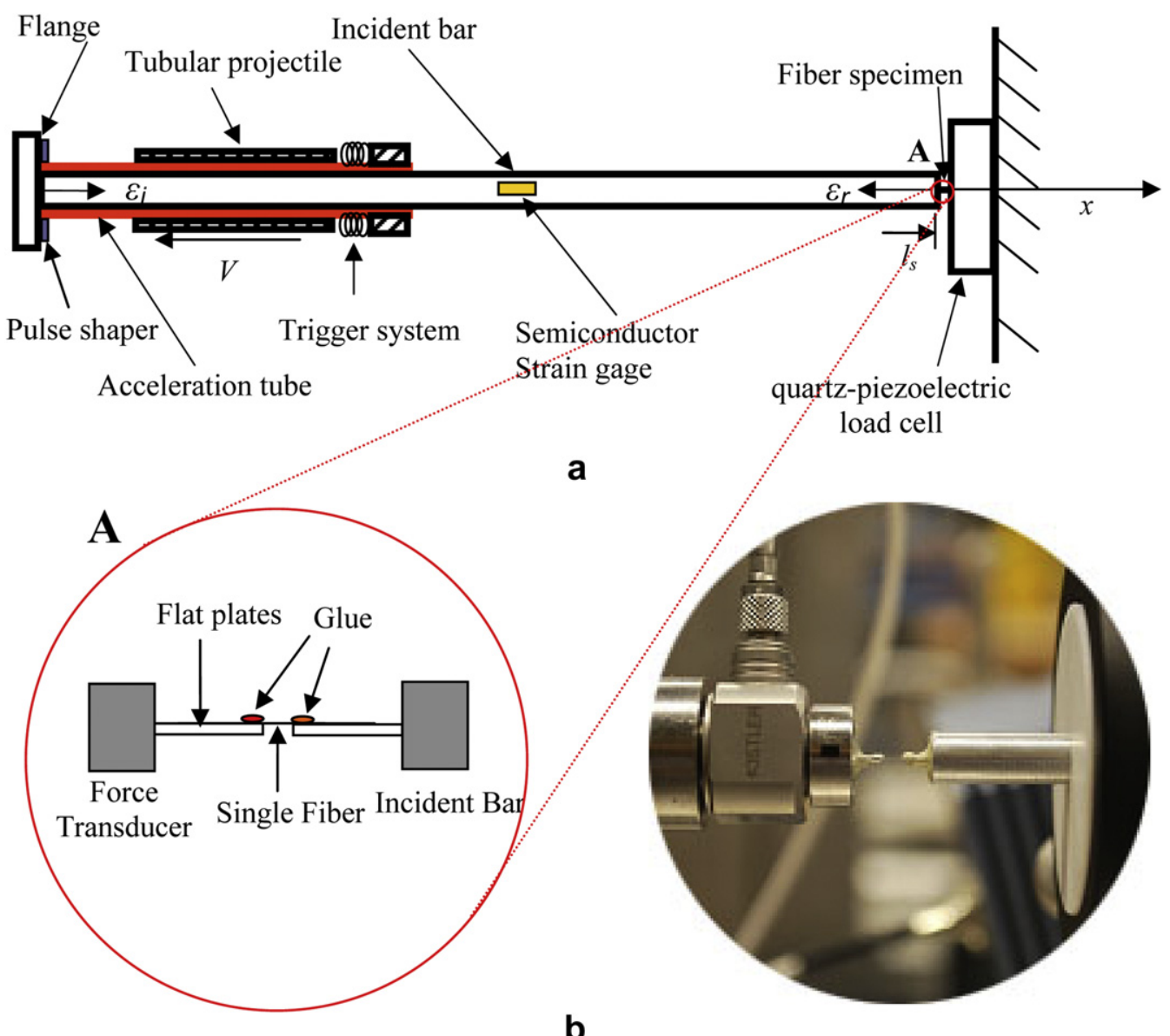

Fig. 8. The experimental setup of a miniature tension bar: (a) schematic diagram (b) a specimen mounting system.

cell. The incident bar is made of an aluminum alloy rod with a diameter of $6.35 \mathrm{~mm}(0.25 \mathrm{in})$ and a length of $1651 \mathrm{~mm}$ (65 in). The impact tube of aluminum with a length of $101.6 \mathrm{~mm}$ ( 4 in) is free to slide on the outer surface of a brass tube. This brass tube separates the incident bar and the striker tube. This separation is necessary to minimize the noise caused by the sliding of striker tube that could mis-trigger the data-acquisition system before impact. The striker tube is launched by a spring system. A pulse shaper is placed between the striker tube and the end flange of the incident bar to generate a smooth and constant-amplitude incident pulse to deform the fiber specimen at an approximately constant strain rate. Glued joints were used to prevent slippage. The mounting arrangement for a single fiber specimen [18] is shown in Fig. 8(b). The two ends of the

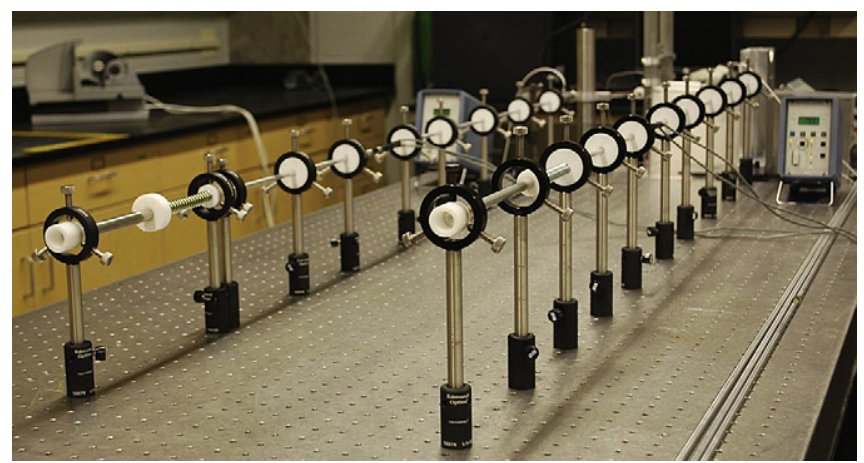

Fig. 9. A photograph of a miniature tension bar for a single fiber test at high strain rate. fiber specimen are glued to two small flat plates attached to the end surfaces of the incident bar and the force transducer. The glue was selected from trial tests such that it would prevent slippage while not affecting the gage section. The small flat plates on which the filament is glued are small enough not to affect the bar-end motion, but are much stiffer than the single filament.

To facilitate uniform loading over the specimen length, short specimens are necessary in the high-rate experiments. A fiber specimen with a short gage length of $2 \mathrm{~mm}$ is connected to the specimen end of the incident bar by an adhesive. No pretension was applied to the specimen. The gage length of the fiber specimen is limited to the $2 \mathrm{~mm}$ to achieve an early dynamic force equilibrium state in the fiber during deformation. The strain rate $(\dot{\varepsilon})$ in the fiber specimen is calculated using the following equation [9]:

$\dot{\varepsilon}=-\frac{v}{l_{s}}=\frac{c_{0}}{l_{s}}\left(\varepsilon_{i}-\varepsilon_{r}\right)$

where $v$ is the particle velocity at the end of the incident bar, $l_{s}$ is the length of the specimen, $c_{0}$ is the elastic bar wave speed in the rod, and $\varepsilon_{i}$ and $\varepsilon_{r}$ are the incident and reflected strains respectively. By integration, we obtain the strain in the fiber specimen as a function of time $t$.

$\varepsilon=\int_{0}^{t} \frac{c_{0}}{l_{s}}\left[\varepsilon_{i}(\tau)-\varepsilon_{r}(\tau)\right] d \tau$

The strain and force signals are recorded from the semiconductor strain gages (KYOWA KSP-2-1K-E4) mounted on the incident bar and 


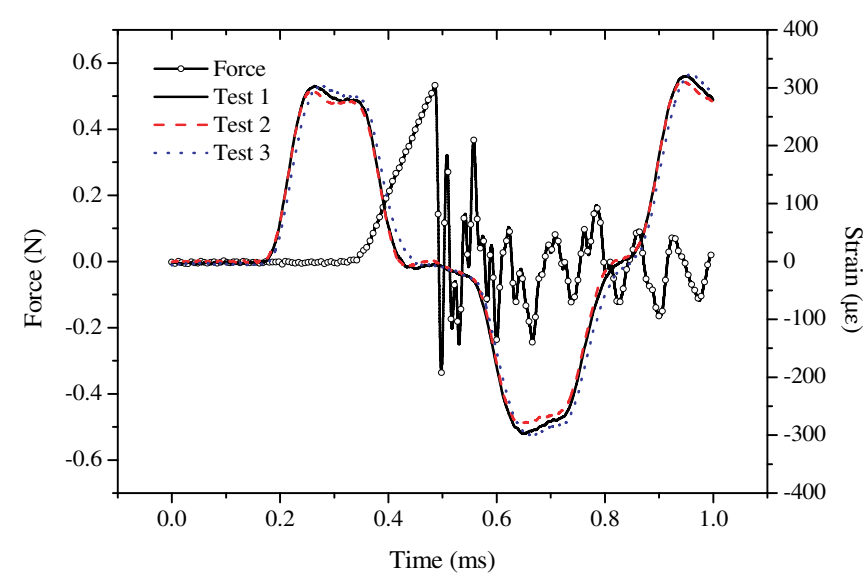

Fig. 10. Typical strain and force signals recorded from a miniature Kolsky tension bar at a strain rate of $\dot{\varepsilon} \approx 1500 \mathrm{~s}^{-1}$.

from the quartz-piezoelectric load cell (Kistler 9712B5), respectively. The precision of the load measurements was demonstrated to have sufficient resolution $[9,19]$. The strain and force histories in the fiber specimen during deformation are shown in Fig. 10. A smooth and constant-amplitude incident pulse shown in Fig. 10 is obtained through the use of a pulse shaper [20,21], which results in constant strain-rate deformation. In this figure, signals from three experiments repeated to achieve a constant strain rate of $\dot{\varepsilon} \approx 1500 \mathrm{~s}^{-1}$ are shown, which demonstrate the repeatability of the loading system. Fig. 10 shows that the force increases linearly in the specimen until failure. This behavior indicates the linear nature of the PPTA single fibers in its longitudinal direction at the high strain rate. The force histories are also overlapping on each other before peak loads.

\subsubsection{Strain rate effects}

In order to examine the strain- rate effects on the tensile failure strength of the PPTA single fibers, we performed tensile experiments at three strain rates: $0.001,1$, and $1500 \mathrm{~s}^{-1}$. Fig. 11 shows the tensile strength distribution of PPTA single fibers as a function of strain rates. As shown in Fig. 11, the experimental results of Kevlar ${ }^{\circledR}$ and Twaron ${ }^{\circledR}$ single fibers do not show significant strain- rate effects on tensile strength within the strain-rate range from

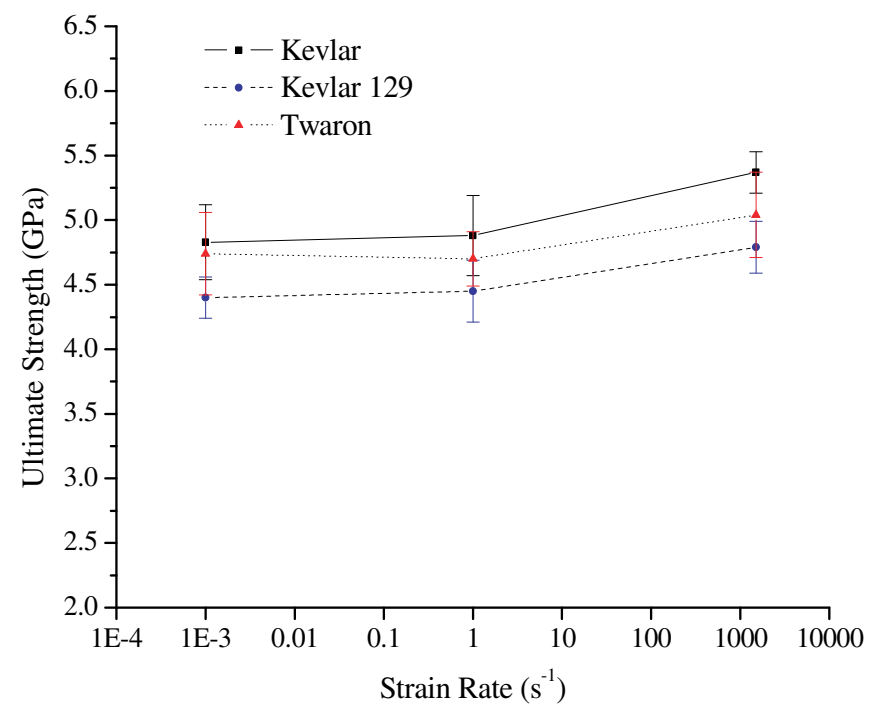

Fig. 11. Variations of the ultimate strengths of PPTA single fibers in the warp direction over strain rates.
Table 3

Longitudinal mechanical properties of PPTA single fiber at high strain rate.

\begin{tabular}{lll}
\hline Fiber type & Tenacity (g/denier) & Ultimate strength (GPa) \\
\hline Kevlar $^{\circledR}$ & 42.2 & $5.37 \pm 0.16(\mathrm{w}) / 5.49 \pm 0.23(\mathrm{f})^{\mathrm{a}}$ \\
Kevlar $^{\circledR} 129$ & 37.7 & $4.79 \pm 0.21$ \\
Twaron $^{\circledR}$ & 39.7 & $5.04 \pm 0.33(\mathrm{w}) / 5.13 \pm 0.21(\mathrm{f})$ \\
\hline
\end{tabular}

${ }^{\mathrm{a}} \mathrm{w}$ and $\mathrm{f}$ indicate the warp and fill direction of the fiber in a single ply.

$\dot{\varepsilon} \approx 0.001 s^{-1}$ to $\dot{\varepsilon} \approx 1500 s^{-1}$. The failure strengths of Kevlar $^{\circledR}$, Kevlar $^{\circledR}$ 129 , and Twaron ${ }^{\circledR}$ single fibers increase only by $8 \%, 8 \%$, and $6 \%$, respectively, as the strain rate increases over 6 decades. The experimental values of longitudinal mechanical properties for PPTA single fiber at high strain rate are summarized in Table 3 . The results listed in Table 3 are with 95\% confidence interval from the results of 15 repeated experiments for each fiber at each strain rate. The results in Table 3 also show that the tensile strength of the fibers in fill direction is slightly higher than that in the warp direction, but not significantly.

Fig. 12 shows the high resolution SEM images showing a fibrillated end of a Kevlar ${ }^{\circledR}$ single fiber failed at both quasi-static and high strain rates. As shown in Fig. 12, there is no significant difference in fracture morphology. This also indicates that the longitudinal behavior of PPTA single fiber does not vary significantly over the strain rate range studied in this research.

\subsubsection{Effect of transverse compression on tensile strength}

In many applications, the high-performance fibers are compressed in the transverse direction, the load then spread in the form of
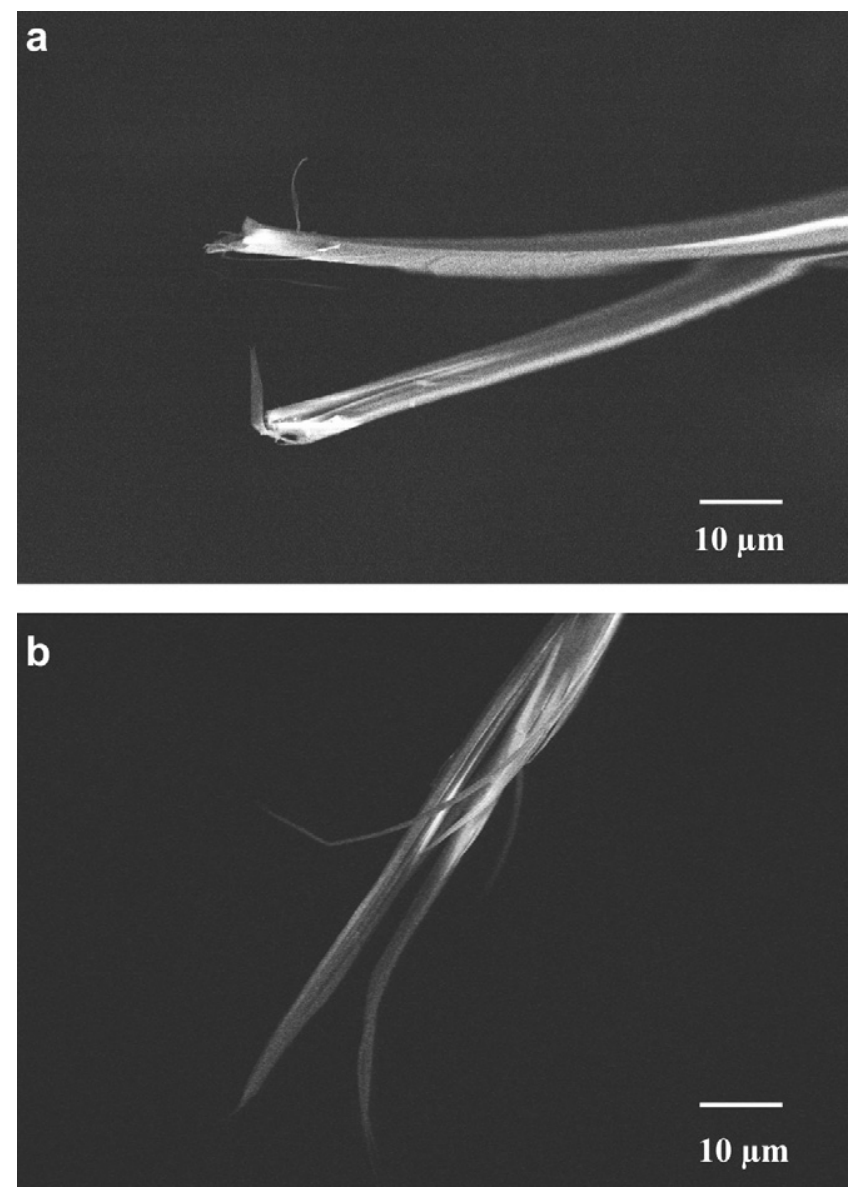

Fig. 12. High resolution SEM images of a failed end of $\operatorname{Kevlar}^{\circledR}$ single fiber at (a) quasistatic and (b) high strain rate. 


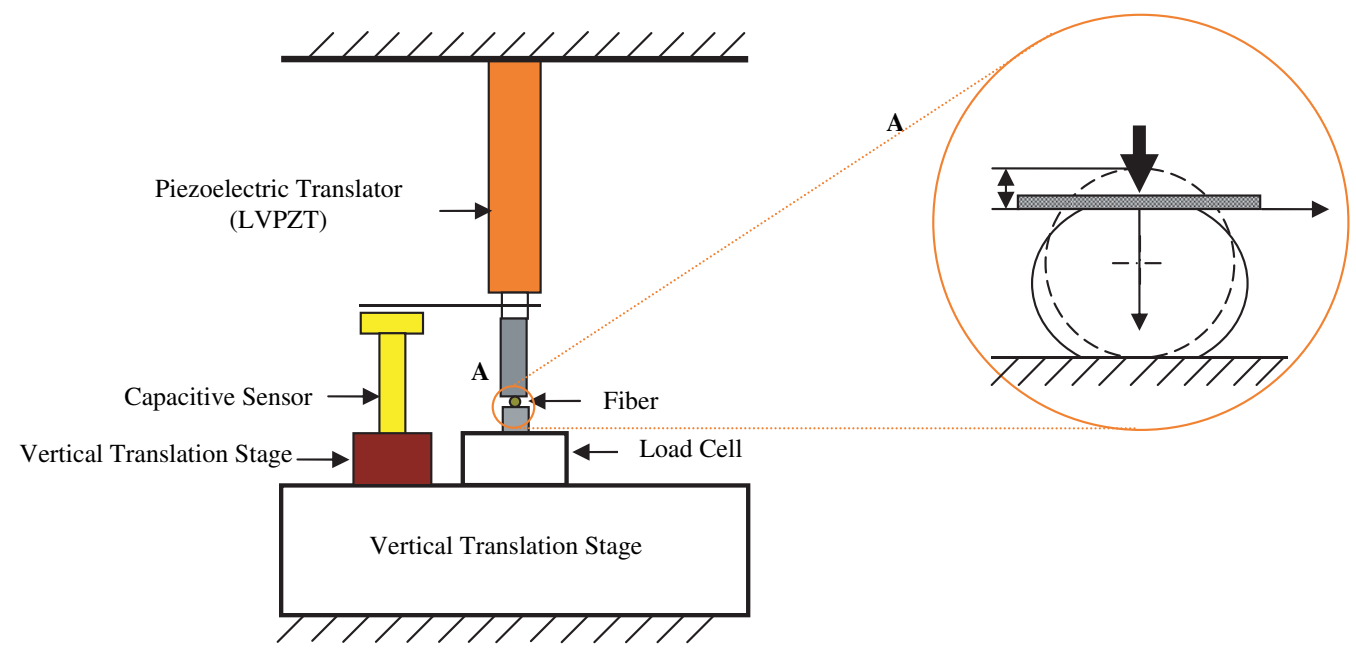

Fig. 13. Schematic diagram of transverse test system.

axial tension. It is thus important to know the axial strength of the fibers after being compressed laterally. In the experiments described here, single PPTA fiber was compressed transversely using a transverse test system [10,19], and then pulled using the miniaturized tension bar shown in Fig. 8. Fig. 13 shows the schematic diagram for measurement of the force and displacement applied to a single fiber transversely. The system includes a piezoelectric translator (Physik

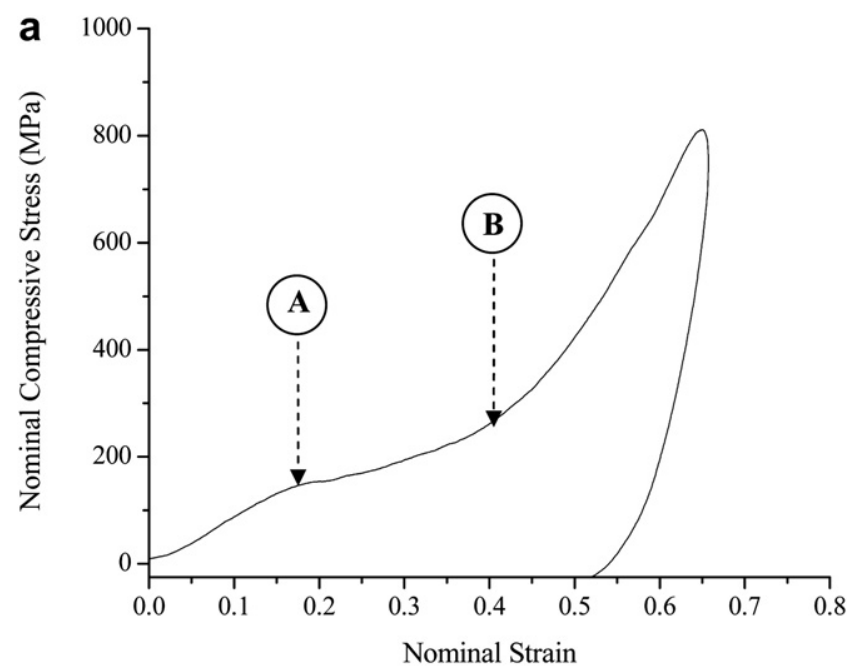

b

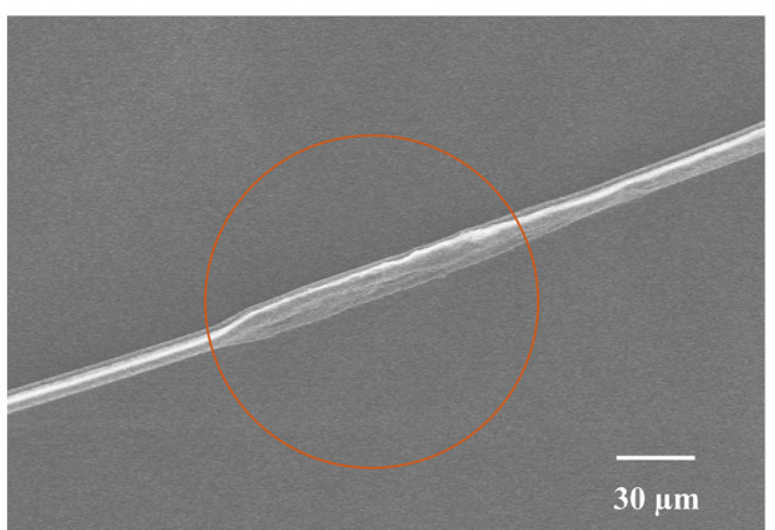

Fig. 14. Transverse compressive stress-strain curve showing ductile behavior of single Kevlar $^{\circledR}$ fiber in one cycle of loading and unloading (a) and deformed shape (b).
Instrument LVPZT, P840.20) traveling up to $30 \mu \mathrm{m}$, push and supporting rods, and a precision vertical translation stage for the proper positioning and alignment. Transverse compressive load is measured directly by a low profile load cell with a capacity of $22.24 \mathrm{~N}(5 \mathrm{lbf})$. The corresponding displacement is measured by a capacitive displacement sensor with sub-nanometer resolution (Physik Instrument D510.100). Single PPTA fiber was compressed transversely at a strain rate of $0.001 / \mathrm{s}$ to about $70-80 \%$ of the fiber diameter. Fig. 14(a) shows the typical transverse compressive response with two distinct transition points, similar to the transverse behavior reported previously on other fibers $[22,23]$. The first transition point (marked A in Fig. 14 (a)) separates linear and nonlinear behaviors at a nominal strain of 15-20\% (nominal strain is defined as the displacement of the bottom surface of the push rod divided by the diameter of the fiber). From this point, the single PPTA fiber begins to yield inducing large residual strain in the fiber. The second transition point (marked B in Fig. 14(a)) arises at a nominal strain of about $40 \%$ in which transverse force increases sharply. After one cycle of loading and unloading, a large residual strain ( $\sim 52 \%$ nominal strain) remains in the fiber as shown in Fig. 14(a). Fig. 14(b) presents the high resolution SEM image showing the deformed Kevlar $^{\circledR}$ single fiber after transverse compression.

In order to investigate the effect of the transverse compression on the tensile behavior of the fiber at high strain rate, single PPTA fiber was compressed transversely up to about $80 \%$ of the fiber diameter and then pulled at the high strain rate of $\dot{\varepsilon} \approx 1500 \mathrm{~s}^{-1}$. The results on the remaining tensile strength after transverse compression are summarized in Table 4 . These experimental results show that the tensile strengths of $\operatorname{Kevlar}^{\circledR}$, $\operatorname{Kevlar}^{\circledR} 129$, and Twaron ${ }^{\circledR}$ single fibers decrease only by $10.8 \%, 11.4 \%$, and $6.3 \%$, respectively, due to the damage in the fibers from large transverse deformation. This is a critical feature of high-performance fibers. The high residual axial tensile strength indicates the strong capacity of these fibers to spread impact loads.

Table 4

Ultimate strength of deformed PPTA fiber at high strain rate.

\begin{tabular}{lll}
\hline Fiber type & $\begin{array}{l}\text { Ultimate strength } \\
\text { of virgin fibers (GPa) }\end{array}$ & $\begin{array}{l}\text { Ultimate strength } \\
\text { of deformed fibers (GPa) }\end{array}$ \\
\hline Kevlar $^{\circledR}$ & $5.37 \pm 0.16(\mathrm{w})$ & $4.79 \pm 0.23(\mathrm{w})^{\mathrm{a}}$ \\
Kevlar $^{\circledR} 129$ & $4.79 \pm 0.21(\mathrm{w})$ & $4.24 \pm 0.21(\mathrm{w})$ \\
Twaron $^{\circledR}$ & $5.04 \pm 0.33(\mathrm{w})$ & $4.72 \pm 0.26(\mathrm{w})$ \\
\hline
\end{tabular}

${ }^{\mathrm{a}} \mathrm{w}$ indicates the warp direction of the fiber in a single ply. 


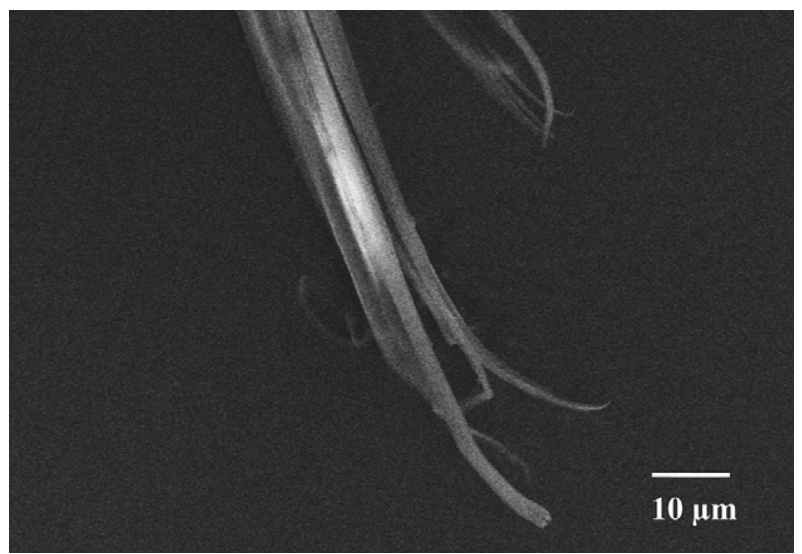

Fig. 15. High resolution SEM image of a broken end of deformed Kevlar ${ }^{\circledR}$ single fiber at high strain rate.

Fig. 15 presents a high resolution SEM image of the fracture surface of a $\operatorname{Kevlar}^{\circledR}$ single fiber failed at high strain rate. Fracture surface by SEM shown in Fig. 15, similar to the failed end in Fig. 12 (b), indicates that the main failure mechanism of the transversely compressed fiber was also related to fibrillation.

However, some of the deformed Kevlar ${ }^{\circledR}$ single fiber that had been imperfectly compressed showed different fracture morphology as shown in Fig. 16(b). Unlike fibrillation shown in Fig. 15, the fracture surface has a sharp cutting edge perpendicular to the longitudinal axis of the fiber. Misalignment of the push rod during transverse compression induces the non-symmetric deformation (inside circle
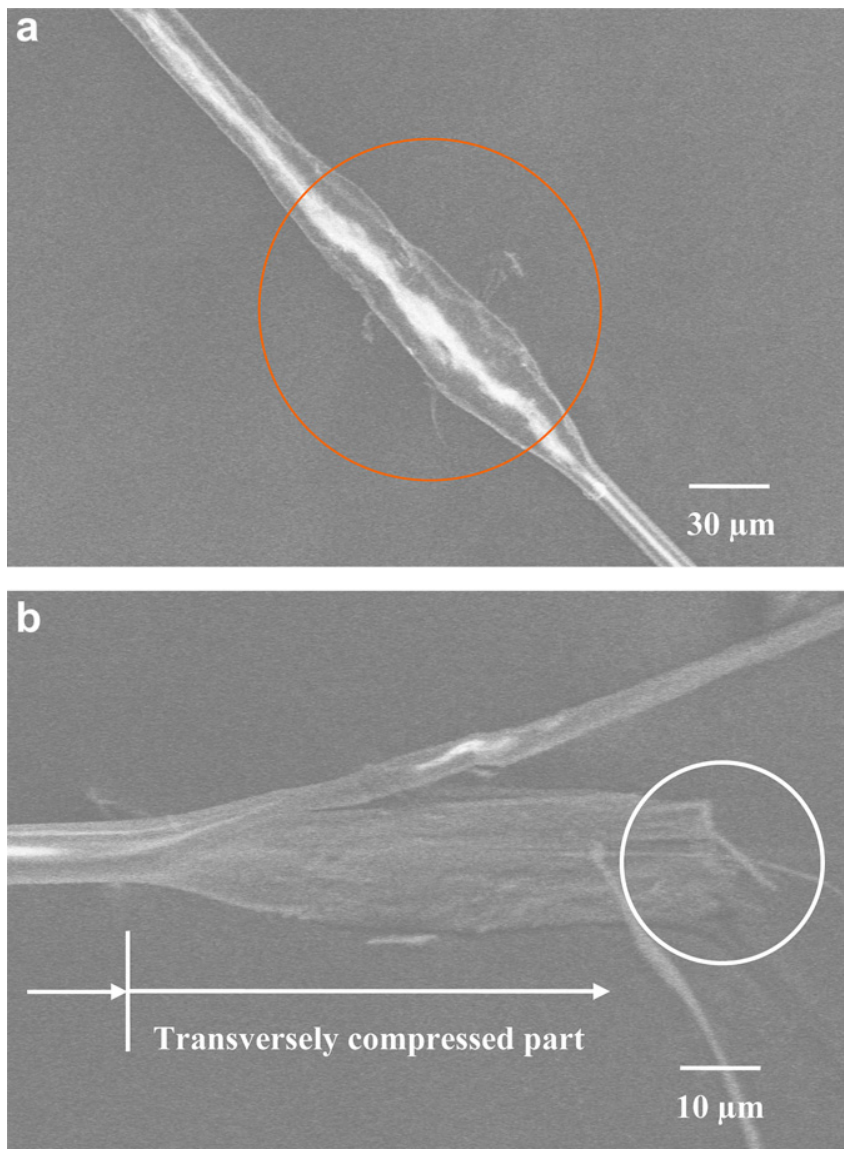

Fig. 16. High resolution SEM image of a deformed $\operatorname{Kevlar}^{\circledR}$ single fiber as imperfectly compressed (a) and a broken end at high strain rate (b). in Fig. 16(a)) which results in the failure of the fiber within the deformed part (marked in Fig. 16(b)). In these Kevlar ${ }^{\circledR}$ single fibers, the remaining tensile strength after transverse compression was measured to be only $2.35 \pm 0.25 \mathrm{GPa}$. These results show a significant reduction of about $50 \%$ in their axial strength, which is caused by the surface damage on the fibers where force is concentrated due to a mis-aligned mis-aligned grips during the initial compression.

\section{Conclusions}

The mechanical behavior of three high-performance PPTA single fibers (Kevlar ${ }^{\circledR}$, Kevlar ${ }^{\circledR} 129$, and $\operatorname{Twaron}^{\circledR}$ ) was studied at both quasi-static and high strain rates. From the quasi-static experiments at six different gage lengths, no significant gage- length effect on the tensile strengths of Kevlar ${ }^{\circledR}$ and Twaron ${ }^{\circledR}$ single fibers was observed. A miniature tension Kolsky bar was modified to conduct high-rate tension experiments. Experimental results at strain rates from $\dot{\varepsilon}=0.001 \mathrm{~s}^{-1}$ to $\dot{\varepsilon} \approx 1500 \mathrm{~s}^{-1}$ showed that the tensile strengths of these PPTA single fibers do not exhibit significant strain-rate effects. The high resolution SEM images showing a fibrillated end of Kevlar ${ }^{\circledR}$ single fiber at both quasi-static and high strain rate also indicate that the longitudinal failure behavior of these PPTA single fibers does not vary significantly in this strain rate range. The experimental results also show that the direction of a fiber in the woven fabric does not affect the tensile strength significantly, although the fibers from the fill direction are slightly stronger.

Transverse compression effect on the axial strengths of the PPTA single fibers at the high strain rate was investigated using a transverse test system and then the miniaturized tension Kolsky bar. The axial strengths of the PPTA single fibers after being compressed laterally were measured. Experimental results showing a small reduction in their tensile strength indicate the strong capacity of these fibers to spread impact loads from transverse directions. Unlike fibrillation, a mis-aligned initial transverse compression results in fracture morphology with a sharp cutting edge perpendicular to the axial direction of the fiber. The damage leads to a reduction in axial strength by about $50 \%$.

\section{References}

[1] Yang HH. Kevlar aramid fiber. New York: John Wiley \& Sons; 1992.

[2] Morton WE, Hearle JWS. Physical properties of textile fibres. New York: John Wiley \& Sons; 1993.

[3] Paraga-Landa B, Hernandez-Olivares F. An analytical model to predict impact behavior of soft armours. Int J Impact Eng 1995;16:455-66.

[4] Gu B. Analytical modeling for the ballistic perforation of planar plain-woven fabric target by projectile. Compos Part B Eng 2003;34:361-71.

[5] Lim CT, Shim VPW, Ng YH. Finite-element modeling of the ballistic impact of fabric armor. Int J Impact Eng 2003;28:12-31.

[6] Shim VPW, Lim CT, Foo KJ. Dynamic mechanical properties of fabric armor. Int J Impact Eng 2001;25:1-15.

[7] Tan VBC, Zeng XS, Shim VPW. Characterization and constitutive modeling of aramid fibers at high strain rates. Int J Impact Eng 2008;35:1303-13.

[8] Languerand DL, Zhang H, Murthy NS, Ramesh KT, Sanoz F. Inelastic behavior and fracture of high modulus polymeric fiber bundles at high strain rates. Mat Sci Eng A 2009;500:216-24.

[9] Cheng M, Chen W. Mechanical properties of $\operatorname{Kevlar}^{\circledR}$ KM2e fiber. J Eng Mater-T ASME 2005;127:197-203.

[10] Lim J, Zheng JQ Masters K, Chen W. Mechanical behavior of A265 single fibers. J Mater Sci 2010;45:652-61.

[11] Sirichaisit J, Young RJ. Tensile and compressive deformation of polypyridobisimidazole (PIPD)-based 'M5' rigid-rod polymer fibres. Polymer 1999;40:3421-31.

[12] Kitagawa T, Yabuki K, Young RJ. An investigation into the relationship between processing, structure and properties for high-moduluss PBO fibres. Part 1. Raman band shifts and broadening in tension and compression. Polymer 2001;42:2101-12.

[13] Kolsky H. An investigation of the mechanical properties of materials at very high rates of loading. Proc Phys Soc B 1949;62:676-700.

[14] Gray G. Classic split-Hopkinson pressure bar testing. In: Kuhn H, Medlin D, editors. ASM International; 2000. p. 462-76. Materials Park, $\mathrm{OH}_{\text {; }}$ 
[15] Gray G, Blumenthal W. Split-Hopkinson pressure bar testing of soft materials. In: Kuhn H, Medlin D, editors. AMS Inernational; 2000. p. 488-96. Materias Park $\mathrm{OH}$.

[16] Meyers MA. Dynamic behavior of materials. New York: John Wiley \& Sons; 1994.

[17] Karl FG. Wave motion in elastic solids. New York: Dover Publications; 1975.

[18] Thomason JL, Kalinka G. A technique for the measurement of reinforcement fibre tensile strength at sub-millimeter gauge lengths. Compos Appl Sci Manuf 2001;32:85-90.

[19] Cheng M, Chen W, Weerasooriya T. Experimental Investigation of the transverse mechanical properties of a single Kevlar ${ }^{\circledR}$ KM2e fiber. Int J Solids Struct 2004;42:6215-32.
[20] Frew DJ, Forrestal MJ, Chen W. Pulse shaping techniques for testing brittle materials with a split Hopkinson pressure bar. Exp Mech 2002; 42:93-106.

[21] Frew DJ, Forrestal MJ, Chen W. Pulse shaping techniques for testing elasticplastic materials with a split Hopkinson pressure bar. Exp Mech 2005;45: 186-95.

[22] Kawabata S. Measurement of the transverse mechanical properties of high performance fibres. J Text Inst 1990;81:432-47.

[23] Singletary J, Davis H, Song Y, Ramasubramanian MK, Knoff W. The transverse compression of PPTA fibers: part II fiber transverse structure. J Mater Sci 2000;35:583-92. 